Tropical Journal of Pharmaceutical Research July 2019; 18 (7): 1547-1552

ISSN: $1596-5996$ (print); 1596-9827 (electronic)

(C) Pharmacotherapy Group, Faculty of Pharmacy, University of Benin, Benin City, 300001 Nigeria.

\title{
High androgen level causes recurrent miscarriage and impairs endometrial receptivity
}

\author{
Yan Su, Haofan Shi ${ }^{\star}$ \\ Department of Gynecology and Obstetrics, International Peace Maternity \& Child Health Hospital, Shanghai 200032, China \\ *For correspondence: Email: saukle@yahoo.com; Tel/Fax: 0086-021-64070434
}

Sent for review: 20 February 2019

Revised accepted: 22 June 2019

\begin{abstract}
Purpose: To investigate the effect of androgen (A2) at different concentrations on human endometrial epithelial cancer cell line (HHUA) using ITRAQ and liquid chromatography-mass spectrometry (LCMS/MS) analysis.

Methods: Human endometrial cells were cultured in Dulbecco Modified Eagle Medium. Total protein was isolated from human endometrial cells and HHUA cells were treated with A2 in three different concentrations $\left(10^{-9}, 10^{-8}\right.$ and $\left.10^{-7} \mathrm{M}\right)$. The proteins were digested using filter-aided sample preparation (FASP) method, and labeled using iTRAQ. The proteins were then subjected to LC-MS/MS. The resultant peptides were identified using Expasy tool, and the up-stream and down-stream proteins were confirmed. Moreover, the up-regulated proteins: isoform 2 of nuclear ubiquitous casein and cyclindependent kinase substrate 1 (NUCKS1), isoform 2 of endothelial differentiation-related factor 1 (EDF1), and acid phosphatase 1 (ACP1) were independently confirmed using western blotting and immunohistochemistry techniques.

Results: Transforming growth factor (TGF), p38 mitogen-activated protein kinase (p38-MAPK), cyclindependent kinase (CDK), and tumor protein p53 (TP53) were the major regulators of the upstream process, and were upregulated RM-linked endometrial epithelial cells. Androgen-associated proteins NUCKS1, EDF1, and ACP1 were significantly responsible for miscarriage-related changes in endometrial tissues $(p<0.05)$. The results showed that a high level of androgen significantly $(p<0.05)$ distorts the expression levels of proteins associated with endometrium development, resulting in impaired endometrial accessibility which led to miscarriage.

Conclusion: Androgen-associated proteins are responsible for changes in endometrial tissues which, in turn, lead to recurrent miscarriage.
\end{abstract}

Keywords: Recurrent miscarriage, Human endometrial cells, Polycystic ovarian syndrome, iTRAQ analysis, Androgens

This is an Open Access article that uses a fund-ing model which does not charge readers or their institutions for access and distributed under the terms of the Creative Commons Attribution License (http://creativecommons.org/licenses/by/4.0) and the Budapest Open Access Initiative (http://www.budapestopenaccessinitiative.org/read), which permit unrestricted use, distribution, and reproduction in any medium, provided the original work is properly credited.

Tropical Journal of Pharmaceutical Research is indexed by Science Citation Index (SciSearch), Scopus, International Pharmaceutical Abstract, Chemical Abstracts, Embase, Index Copernicus, EBSCO, African Index Medicus, JournalSeek, Journal Citation Reports/Science Edition, Directory of Open Access Journals (DOAJ), African Journal Online, Bioline International, Open-J-Gate and Pharmacy Abstracts

\section{INTRODUCTION}

Recurrent miscarriage (RM) is defined as pregnancy loss in more than three clinical pregnancies starting from conception time to 25 weeks [1]. The causes of $R M$ are not fully understood, but it is associated with multiple risk factors in many cases. The risk factors include polycystic ovaries, chromosomal abnormalities, autoimmune diseases, and genetic factors [2]. 
However, in majority of RM cases, the underlying causes are not clear. It has been suggested that miscarriage is associated with mental disorders and anxiety, thereby affecting the quality of life [3]. Polycystic ovarian syndrome (PCOS) accounts for more than $80 \%$ of RM in women. It is a hormonal disorder which occurs in $8-12 \%$ of women population in their reproductive period, and it is mostly associated with anovulation with high levels of androgen. Women with high levels of androgen tend to have a higher risk of miscarriage and implantation failure than normal females [4].

The key function of androgens in females is aromatization to estrogens. They are present in the uterus, vaginal mucosa and ovarian follicles. Androgens are also abundantly present during ovulation in the follicular region [5]. Androgens are precursors in the biosynthesis of estrogens, and are present in high levels during early pregnancy in the uterine location. However, a study on mouse model reported that delayed implantation and low androgen level are associated with delay in embryo attachment. Excess androgen leads to abnormal gene expression. Therefore, the effect of high androgen level on endometrial tissues is linked with RM, particularly in individuals with PCOS [6]. There are also studies which reported elevated levels of androgen in women with RM [7].

In view of the fact that high a level of androgen is lethal to the endometrium and leads to $\mathrm{RM}$, the effect of androgen (A2) on HUAA cells at three different concentrations viz. medium $\left(10^{-9} \mathrm{M}\right)$, optimum $\left(10^{-8} \mathrm{M}\right)$, and high $\left(10^{-7} \mathrm{M}\right)$ was investigated in this study. The investigation also focused on the effect of A2 on protein expressions using isobaric labeling along with LC-MS/MS for profiling the A2-treated HUAA cells.

\section{EXPERIMENTAL}

\section{Ethical statement}

This investigation was approved by the Research and Ethical committee of the International Peace Maternity \& Child Health Hospital, Shanghai, 200032, China (approval no. IPMCHH/DGO/2017/28-R). All procedures were carried out following the NIH guidelines for the use of cell lines in biomedical research [8].

\section{Cell culture}

Human endometrial cells were purchased from Sigma-Aldrich and cultured in Dulbecco Modified Eagle Medium (Thermo Fisher) supplemented with $8 \%$ BSA. The HHUA cells were purchased from HiMedia Shangai and cultured in Ham's F12 Nutrient Mixture (Thermo Fisher) supplemented with $8 \%$ BSA and $50 \mu \mathrm{L}$ of streptomycin. At confluence, the culture medium was substituted with RPMI 1640 containing $8 \%$ FBS. The medium was treated with various concentrations of $\mathrm{A} 2$ i.e. $10^{-9}, 10^{-8}$ and $10^{-7} \mathrm{M}$.

\section{Protein isolation and digestion}

Total protein was isolated from the human endometrial cells and HHUA cells. The cells were initially treated with $\mathrm{A} 2$ at various concentrations, and the cell walls were digested using RIPA cell lysis buffer at $90{ }^{\circ} \mathrm{C}$ for $10 \mathrm{~min}$. The mixture was further sonicated in ice-cold conditions with 3 cycles at 1-min intervals. The extract was then centrifuged at $13000 \mathrm{rpm}$ for $45 \mathrm{~min}$ after incubating at $85{ }^{\circ} \mathrm{C}$. The protein concentration of the supernatant was estimated using Bradford assay.

\section{iTRAQ labeling}

Filter Aided Sample Preparation (FASP) method was used for generating peptides by digesting the proteins samples. About $300 \mu \mathrm{g}$ of sample was mixed with $50 \mu \mathrm{L}$ of $6 \%$ SDS solution and $100 \mu \mathrm{L}$ of Tris- $\mathrm{HCl}$ buffer, $\mathrm{pH}$ 7.6. The protein sample mixture was further mixed with $50 \mu \mathrm{L}$ of DTT solution and allowed to incubate at $90^{\circ} \mathrm{C}$ for $10 \mathrm{~min}$. The sample was allowed to cool to 21 ${ }^{\circ} \mathrm{C}$, and was then incubated in ice for $10 \mathrm{~min}$. After filtration using syringe filter, $200 \mu \mathrm{L}$ of UT buffer was added, followed by centrifugation at $12000 \mathrm{rpm}$ for $20 \mathrm{~min}$ at $15^{\circ} \mathrm{C}$. The filtrate was treated with $200 \mu \mathrm{L}$ of dissolution buffer and filtered through an ultrafilter membrane, followed by centrifugation at $12000 \mathrm{rpm}$ for $20 \mathrm{~min}$. Then, the sample was digested with $30 \mu \mathrm{L}$ of trypsin buffer at $35^{\circ} \mathrm{C}$ for $24 \mathrm{~h}$. The resultant digest was transferred into a fresh tube and the peptide concentration was determined by measuring absorbance at $280 \mathrm{~nm}$. Then, each of the three peptide samples was labeled using 8-plex ITRAQ reagent (Sigma-Aldrich) according to the manufacturer's protocol.

\section{Cation exchange fractionation}

Coulter Gold HPLC system equipped with 2.1mm-inner diameter $\times$ 100-mm-long PolySULPHOETHYL-A column was employed for cationic exchange fractionation. The peptide samples were loaded onto the column and washed with solvent A which comprised $25 \%$ (v/v) $10 \mathrm{mM} \mathrm{KH}_{2} \mathrm{PO}_{4}$. The peptide fractionation was carried out using a linear binary gradient of solvent $B$ at a flow rate of $0.2 \mathrm{ml} / \mathrm{min}$ over 75 
min. The absorbance of the eluent was read at $220 \mathrm{~nm}$ at $60 \mathrm{sec}$ intervals, and the fractions were collected. The samples were mixed with separate fractions, desalted on $\mathrm{C}-18$ cartridges, and air-dried in a vacuum centrifuge tube.

\section{LC-MS/MS and Uniprot analysis}

Analysis on LC-MS/MS was carried out by loading $7 \mu \mathrm{g}$ of peptide samples from a given fraction into the EASY-nLC column containing solvent $\mathrm{C}$, and eluted using solvent $\mathrm{D}$. The flow rate was set at $200 \mathrm{\eta l} / \mathrm{min}$ for $90 \mathrm{~min}$. Q-Exactive survey scans were carried out and the data were acquired in the +ve ion mode in the range of 300$800 \mathrm{~m} / \mathrm{z}$. The scan was set at $60,000 \mathrm{~m} / \mathrm{z}$ HCD resolution spectra and the MS/MS output was obtained using a data-dependent technique. The peptides were identified by conducting a similarity search using Expasy Tool searched against the UniProt Databases against the protein sequences of Homo sapiens. The parameters and algorithm were set at a tolerance of $\pm 22 \mathrm{ppm}$ of peptide mass, and $0.2 \mathrm{Da}$ for fragment mass.

\section{Western blotting}

The protein samples from HUAA and the endometrium cells were initially separated using $12 \%$ sodium dodecyl sulfate polyacrylamide gel electrophoresis (SDS-PAGE electrophoresis). The proteins samples were then transferred to a nitrocellulose membrane (Biorad) and incubated for $60 \mathrm{~min}$ using a blocking buffer. The membranes were treated with their specific primary antibodies for $24 \mathrm{~h}$ at 4 ${ }^{\circ} \mathrm{C}$, and were then washed 3 - 5 times with TTBS mixture, followed by incubation with secondary antibody for $60 \mathrm{~min}$ at $22^{\circ} \mathrm{C}$. The membrane was washed three times and the intensities of the protein blots were determined and evaluated using Imaging System from LI-COR (Odyssey).

\section{Immunohistochemistry}

The tissue samples and the cells were fixed in 4 $\%$ paraformaldehyde and incubated at $85^{\circ} \mathrm{C}$ with citrate buffer. The samples were permeabilized with PBS. Immunohistochemical analysis was then carried out on the endometrial sections using peroxidase kit as per manufacturer's protocol. The sections were blocked with $7 \%$ BSA and incubated with the specific antibodies for $24 \mathrm{~h}$ at $6^{\circ} \mathrm{C}$. The sections were washed with PBS, and were further blocked with their respective secondary antibodies, followed by counterstaining with DAPI. The cells were then fixed in a coverslip, incubated with their specific primary antibodies, and photographed using Leica Microscope.

\section{Statistical analysis}

Data are expressed as mean \pm SEM, and were analyzed using SPSS version 18.0. (SPSS Inc, USA). Student's t-test was used for comparison between groups. Values of $p<0.05$ were considered statistically significant.

\section{RESULTS}

\section{HHUA cell profiling}

Proteomic alterations in HHUA cells were determined using ITRAQ analysis. The proteomic alterations were compared with differentially expressed proteins (up-regulated and downregulated proteins) in HHUA cells. The mapping of the protein spot in HHUA cells was identified and the key proteins were quantified. The results are shown in Table 1, which also shows the results of ITRAQ analysis from the differently expressed proteins in the endometrial epithelial cells. These proteins were categorized into two different groups i.e. up-regulated proteins and down-regulated proteins, based on their specific expression patterns using Uniprot analysis.

\section{Upstream analysis}

Upstream analysis revealed that TGF, P38MAPK, cyclin-dependent kinase, and TP53 were the major regulators of the upstream process (Table 2). It is evident from Table 2 that the P38MAPK gene activated NUCKS1, GAPDH, MYOF, MYH9 and TP53I3 proteins, whereas NUCKS1 and EDF1 were regulated by TP53 gene. Thus, these proteins which up-regulate the endometrial epithelial cells are associated with RM.

\section{Western blotting}

The ITRAQ analysis was followed by western blotting for analysis of proteomics. The expression levels of NUCKS1, EDF1, and ACP1 from the HUAA cells were determined because these proteins are associated with RM. Figure 1 shows the results of western blot analysis for the expression levels of NUCKS1, EDF1, and ACP1. The results are consistent with data from iTRAQ analysis. The same expression analysis was carried out using the endometrial cells (Figures $2 \mathrm{~A}, 2 \mathrm{~B}$ and 2C). The results revealed that NUCKS1 was down-regulated by $A 2$ at doses of $10^{-7}$ and $10^{-8} \mathrm{M} \mathrm{A} 2$ (Figure $2 \mathrm{~A}$ ), while EDF1 (Figure $2 \mathrm{~B}$ ) and ACP1 (Figure $2 \mathrm{C}$ ) were up-regulated by $A 2$ at doses of $10^{-7}$ and $10^{-8} \mathrm{M}$, relative to the dose of $10^{-9} \mathrm{M}$. 
Table 1: Proteins expressed in the endometrial tissues

\begin{tabular}{lll}
\hline Accession number & Name of protein & Acronym \\
\hline P55081 & Microfibrillar-associated protein 1 & MFAP1 \\
P52655 & Transcription initiation factor IIA subunit 1 & GTF2A1 \\
A8K9D2 & Mitochondrial ribosomal protein L18 & MRPL18 \\
P04406 & Glyceraldehyde-3-phosphate dehydrogenase & GAPDH \\
P06733 & Alpha-enolase & ENO1 \\
Q9H1E3-2 & Isoform 2 of Nuclear ubiquitous casein and cyclin-dependent & NUCKS1 \\
& kinase substrate 1 & MYOF \\
H0YD14 & Myoferlin & HSP90AB1 \\
P08238 & Heat shock protein HSP 90-beta & TUBB \\
Q5JP53 & Tubulin beta chain & MYH9 \\
P35579 & Myosin-9 & GPI PE \\
P06744 & Glucose-6-phosphate isomerase & TUBB6 \\
Q9BUF5 & Tubulin beta-6 chain & EDF1 \\
O60869-2 & Isoform 2 of Endothelial differentiation-related factor 1 & TP53I3 \\
B4DMQ7 & Tumor protein p53 inducible protein 3, isoform CRA_C & CACYBP \\
Q9HB71 & Calcyclin-binding protein & PGRMC2 \\
O15173 & Membrane-associated progesterone receptor component 2 & DRG1 PE \\
Q9Y295 & Developmentally-regulated GTP-binding protein 1 & ATP6V1B2 \\
P21281 & V-type proton ATPase subunit B, brain isoform & ACP1 \\
G5E9R5 & Acid phosphatase 1 & NBAS \\
G1U126 & Neuroblastoma-amplified sequence & \\
\hline
\end{tabular}

\section{Expression analysis}

Immuno-histochemical results from analysis of expressions of NUCKS1, EDF1, and ACP1 in the epithelial samples are presented in Figure 3. It was observed that NUCKS1 (Figure 3A), EDF1 (Figure 3B) and ACP1 (Figure 3C) were localized centrally in the endometrial epithelium.

Table 2: Up-stream regulator proteins as revealed through ITRAQ analysis

\begin{tabular}{lll}
\hline $\begin{array}{l}\text { Upstream } \\
\text { regulator }\end{array}$ & $\begin{array}{l}\text { Molecule } \\
\text { type }\end{array}$ & Molecules targeted \\
\hline P38 MAPK & Activator & $\begin{array}{l}\text { NUCKS1, GAPDH, MYOF, } \\
\text { MYH9, TP53I3 }\end{array}$ \\
TP53 & Regulator & NUCKS1, EDF1 \\
TGF-Beta & Kinase & NUCKS1, MYOF, MYH9 \\
\hline
\end{tabular}
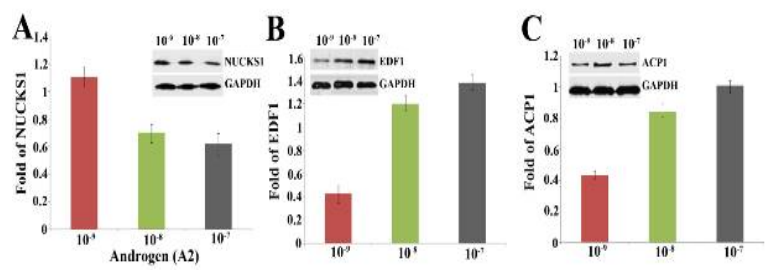

Figure 1: Results of Western blotting. (A) NUCKS1; (B) EDF1, and (C) ACP1 expressions at different concentrations of A2. Data are presented as mean \pm SD. $p<0.05$

\section{DISCUSSION}

Miscarriage is defined as pregnancy loss from the time of conception to within 24 weeks of gestation [9]. On the other hand, RM refers to

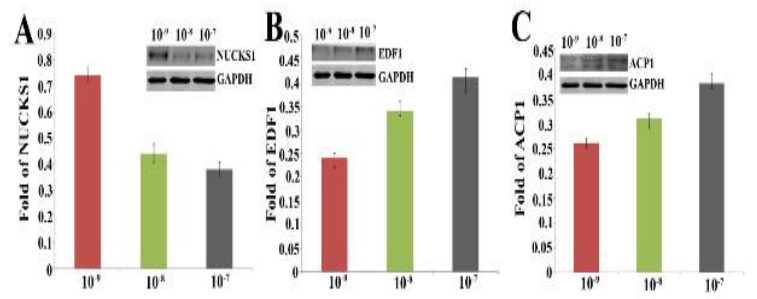

Figure 2: Western blot result of (A) NUCKS1, (B) EDF1, and (C) ACP1 expression in the endometrial cells at different concentrations of A2. Data are presented as mean \pm SD. $p<0.05$
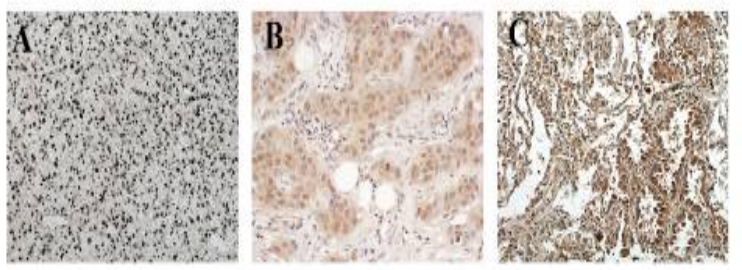

Figure 3: Immuno-histochemical results of (A) NUCKS1, (B) EDF1, and (C) ACP1 expressed in the endometrial cells

three or more consecutive failed pregnancies [1]. The etiology of recurrent miscarriage is not properly understood. However, in most cases, it is associated with several risk factors which include chromosomal aberrations and endocrine factors. In addition, the risk of RM increases with successive pregnancy loss [10]. It has also been reported that risk factors for RM may be immunological, and may be associated with polycystic ovary apart from spontaneous abortions [11]. On the other hand, it has been 
reported that PCOS is a major factor responsible for high incidence of RM, and that the underlying causes of RM are genetic factors, as well as endocrine and autoimmune diseases [12].

Moreover, hormonal factors and aberrations in the endocrine glands, pituitary glands, thyroid glands, and ovaries are major contributors to RM [13]. Thus, the pathogenicity of RM is very complex and has not been properly understood. There are also studies which suggest that the disruptions in the endometrial androgen compartments lead to RM. Thus, the purpose of the present study was to determine the impact of androgen (A2) on endometrium receptivity in women with RM. Results from the LC/MS experiment revealed that most of the proteins expressed in the endometrial cells were A2dependent, implying that such proteins may be directly associated with RM. Furthermore, the analysis of samples from patients showed the expressions of key proteins such as NUCKS1, EDF1, and ACP1 in the epithelial tissues of endometrial cells.

In a study, it was also reported that cyclindependent kinase which is involved in regulating the cell cycle is inhibited by NUCKS1 [15]. Moreover, CDK inhibitors of protein kinases are involved in cell proliferation, apoptosis and cell differentiation [16]. However, in the present study, it was observed that the level of NUCKS1 in endometrial cells was reduced by increasing the dose of A2. In addition, knockdown of NUCKS1 led to decreases in cell proliferation, migration, and invasion of HUAA cells. It has been reported that inhibition of cyclin-dependent kinases led to the destruction of placental embryo in endometrial cells [17]. This suggests that decreases in CDK levels in endometrial cells are associated with $\mathrm{RM}$, especially with high $\mathrm{A} 2$ levels. On the other hand, it has been reported that DNA repair and cell differentiation in RM are influenced by p53 gene [18].

In the present study, p53 and NUCKS1 levels were higher in the RM group than in the control group. The p53 gene regulates downstream proteins of NUCKS1 which are linked to DNA repair, cell differentiation, and apoptosis. The proteins of the upstream regulators also play key roles in RM. Furthermore, p38 MAPK gene delays the implantation process by blocking these specific genes [19]. In the present study, proteomics analysis also showed that the p53 gene pathway was activated by increasing levels of $A 2$, thereby downregulating NUCKS1.

\section{CONCLUSION}

The results obtained in this study reveal that androgen-associated proteins are responsible for changes in endometrial tissues linked to recurrent miscarriage. Proteomics study also revealed that increased levels of androgen in women cause RM. These results provide insight into the relationship between high androgen levels and the endometrium in recurrent miscarriage. The results are expected to contribute significantly to the understanding of some of the mechanisms involved in RM.

\section{DECLARATIONS}

\section{Acknowledgement}

The authors acknowledge the support from the International Peace Maternity and Child Health Hospital, Shanghai, China.

\section{Conflict of interest}

No conflict of interest exists with regard to this work.

\section{Contribution of authors}

We declare that this work was done by the authors named in this article and all liabilities pertaining to claims relating to the content of this article will be borne by the authors. The study was performed by Yan Su under supervision of Haofan Shi. Haofan Shi designed the whole study.

\section{Open Access}

This is an Open Access article that uses a funding model which does not charge readers or their institutions for access and distributed under the terms of the Creative Commons Attribution License (http://creativecommons.org/licenses/by/ 4.0) and the Budapest Open Access Initiative (http://www.budapestopenaccessinitiative.org/rea d), which permit unrestricted use, distribution, and reproduction in any medium, provided the original work is properly credited.

\section{REFERENCES}

1. Rasmark RE, Hellgren $M$, Hjertberg $R$, Blomqvist $L$, Matthiesen L, Henic E, Lalitkumar S, Strandell $A$. Treatment efficacy for idiopathic recurrent pregnancy loss - a systematic review and meta-analyses. Acta Obstet Gynecol Scand 2018; doi: 10.1111/aogs.13352.

2. Sköld C, Bjørge T, Ekbom A, Engeland A, Gissler $M$, Grotmol T, Madanat-Harjuoja L, Gulbech Ording A, Stephansson $O$, Trabert $B$, et al. Preterm delivery is 
associated with an increased risk of epithelial ovarian cancer among parous women. Int $J$ Cancer 2018; 143(8): 1858-1867.

3. Zhu CS, Tan TC, Chen HY, Malhotra R, Allen JC, Østbye $T$. Threatened miscarriage and depressive and anxiety symptoms among women and partners in early pregnancy. J Affect Disord 2018; 237: 1-9.

4. Bellver J, Rodríguez-Tabernero L, Robles A, Muñoz E, Martínez F, Landeras J, García-Velasco J, Fontes J, Álvarez M, Álvarez C, Acevedo B; Group of interest in Reproductive Endocrinology (GIER) of the Spanish Fertility Society (SEF). Polycystic ovary syndrome throughout a woman's life. J Assist Reprod Genet 2018; 35(1): 25-39.

5. Pepe G, Locati M, Della Torre S, Mornata F, Cignarella $A$, Maggi $A$, Vegeto $E$. The estrogen-macrophage interplay in the homeostasis of the female reproductive tract. Hum Reprod Update 2018; 24(6): 652-672

6. Ezeh U, Huang A, Landay M, Azziz R. Long-Term Response of Hirsutism and Other Hyperandrogenic Symptoms to Combination Therapy in Polycystic Ovary Syndrome. J Womens Health (Larchmt) 2018; 27(7): 892-902.

7. Yang HL, Zhou WJ, Gu CJ, Meng YH, Shao J, Li DJ, Li $M Q$. Pleiotropic roles of melatonin in endometriosis, recurrent spontaneous abortion, and polycystic ovary syndrome. Am J Reprod Immunol 2018; 80(1): e12839

8. Geraghty RJ, Capes-Davis A, Davis JM, Downward J, Freshney RI, Knezevic I, Lovell-Badge R, Masters JRW, Meredith J, Stacey GN, et al. Guidelines for the use of cell lines in biomedical research. Br J Cancer 2014; 111(6): 1021-1046.

9. Shahine L, Lathi R. Recurrent pregnancy loss: evaluation and treatment. Obstet Gynecol Clin North Am 2015; 42(1): 117-134.

10. Page JM, Silver RM. Genetic Causes of Recurrent Pregnancy Loss. Clin Obstet Gynecol 2016; 59(3): 498508.
11. Wagner MM, Visser J, Verburg $H$, Hukkelhoven CWPM, Van Lith JMM, Bloemenkamp KWM. Pregnancy before recurrent pregnancy loss more often complicated by post-term birth and perinatal death. Acta Obstet Gynecol Scand 2018; 97(1): 82-88.

12. Yang HL, Zhou WJ, Gu CJ, Meng YH, Shao J, Li DJ, Li $M Q$. Pleiotropic roles of melatonin in endometriosis, recurrent spontaneous abortion, and polycystic ovary syndrome. Am J Reprod Immunol 2018; 80(1): e12839

13. Hyer S, Balani J, Shehata H. Metformin in Pregnancy: Mechanisms and Clinical Applications. Int $\mathrm{J} \mathrm{Mol} \mathrm{Sci}$ 2018; 19(7): E1954

14. Samtani R, Sharma N, Garg D. Effects of EndocrineDisrupting Chemicals and Epigenetic Modifications in Ovarian Cancer: A Review. Reprod Sci 2018; 25(1): 718.

15. Huang YK, Kang WM, Ma ZQ, Liu YQ, Zhou L, Yu JC. NUCKS1 promotes gastric cancer cell aggressiveness by upregulating IGF-1R and subsequently activating the PI3K/Akt/mTOR signaling pathway. Carcinogenesis. 2018; doi: 10.1093/carcin/bgy142.

16. David CJ, Massagué J. Contextual determinants of TGF $\beta$ action in development, immunity and cancer. Nat Rev Mol Cell Biol 2018; 19(7): 419-435.

17. Tsamou M, Vrijens K, Madhloum N, Lefebvre W, Vanpoucke C, Nawrot TS. Air pollution-induced placental epigenetic alterations in early life: a candidate miRNA approach. Epigenetics 2018; 13(2): 135-146

18. Arias-Sosa LA, Acosta ID, Lucena-Quevedo E, MorenoOrtiz H, Esteban-Pérez C, Forero-Castro M. Genetic and epigenetic variations associated with idiopathic recurrent pregnancy loss. J Assist Reprod Genet 2018; 35(3): 355-366.

19. Rahman TU, Ullah K, Guo MX, Pan HT, Liu J, Ren J, Jin $L Y$, Zhou YZ, Cheng $Y$, Sheng JZ, Huang HF. Androgen-induced alterations in endometrial proteins crucial in recurrent miscarriages. Oncotarget 2018; 9(37): 24627-24641 